\title{
In the Blood: A Contemporary American Common (Wo)man Tragedy
}

\section{Dina Amin*}

Gaston Bachelard proclaims in The Poetics of Space, that, "A house constitutes a body of images that give mankind proofs or illusions of stability $(1969,17)$. He also states that a, - "house [...] [w]ithout it, man would be a dispersed being. It maintains him through the storms of the heavens and through those of life. It is body and soul. It is the human being's first world. Before he is 'cast into the world,' [...] And always, in our daydreams, the house is a large cradle" (7). In the Blood is a play, by Suzan Lori-Parks (2000), that tells the story of an African-American homeless woman who strives to alter her "cast into world" condition and create a "large cradle" out of her home on the streets. In the play, Hester is a mother of five illegitimate children, who appropriates part of the street under a bridge as her home (Lori-Parks 2000, n. pag.). As a homeless, uneducated woman, and single mother of five, Hester battles with all forms of social injustices, paramount among those is stereotyping and exploitation in contemporary US society. While battling with the various stereotypes attributed to African-Americans on the one hand, and poor women who have children out of wedlock, on the other, Hester struggles to give herself agency even though her social condition and class deprive her of any sense of power.

This paper argues that Hester's plight is a common person's tragedy, as articulated by Arthur Miller in "Tragedy and the Common Man" (Miller 2015, n. pag.). Her excessive need to control her life by creating a home for herself and her children on the street, is her hamartia, as her attachment to her space confirms that she implicitly believes that home is, "the non-I that protects the I" (Bachelard 1969, 5). Hester's tragedy springs from her refusal to accept her limitations as well as her strong attachment to a space that is not hers to have,

\footnotetext{
* Associate Professor of Theatre, Director of Theatre Program, Department of the Arts, American University in Cairo

Cairo Studies in English - 2020(2): https://cse.journals.ekb.eg/
} 
the street. Her appropriation of public space is her way to exercise power over her life and the lives of her children, and while it dehumanizes her socially, it provides her with an alternative to living in homeless shelters where she would have to abide by systemic rules and restrictions. Living on the streets is a symbol of her freedom from all forms of authority, as on the street she lives according to her rules and values. Furthermore, the street constitutes a central space in society that, obviously, homeless shelters do not. On the contrary, shelters can be perceived as marginal existence in, indeed a removal from, society. However, living on the streets makes Hester and her five illegitimate children neither in nor out of the dominant society. She normalizes their 'in-betweenness' by showing that living on the street is her choice regardless of the wishes of that society or the authorities. While agents within her community resist her freedom to live on public property under a bridge, she pushes back in an attempt to demonstrate that she has the right as much as anyone else to make decisions for herself and improve her marginal status - from her perspective - in whatever fashion that suits her. However, "[s]truggling against her fate seems doomed from the start" (Fraden 2007, 447) for she fails in her pursuit of independence and control over life, largely because of her lack of means and her illiteracy. Hester's plight is by all means a tragedy of a common person. While,

Parks's drama does not fit neatly into literary definitions of tragedy because it focuses on the sometimes unfortunate and more often terrible circumstances of everyday people. In addition, many of her protagonists are black. (Colbert 2018, 199-200)

In spite of this statement, which Soyica Diggs Colbert articulates cynically in the face of Parks's detractors who believe that her writing is beneath the dignity of tragedy, Arthur Miller poses a similar statement by stating that, "[i]n this age [...] [f]or one reason or another, we [are] often held to be below tragedy-or tragedy above us" (Miller 2015, n. pag.). By "us", herein, Miller refers to the modern person, who is neither royalty nor special in any particular way, and who, because of his/her ordinary circumstances, cannot be considered a candidate for tragedy because of literary tradition. After all, the doyen of the 
theory of tragedy and tragic heroes, Aristotle, explains them in his seminal work, The Poetics, saying that

the character [...] must be one who is highly renowned and prosperous - a personage like Oedipus, Thyestes, or other illustrious men of such families. [...] A well-constructed plot should, therefore, be single in its issue [...] The change of fortune should not be from bad to good, but, reversely, from good to bad. It should come about as the result not of vice, but of some great error or frailty, in a character either such as we have described, or better rather than worse. (Aristotle 1961, 76)

Miller, however, mocks this traditional notion strongly and shoves it aside saying that human dignity is an essential quality in all human kind, and that, "From Orestes to Hamlet, Medea to Macbeth, the underlying struggles [are] that of the individual attempting to gain his "rightful" position in his society" (2015, n. pag.). From this point view, In the Blood is a Miller-type tragedy that traces the downfall of a little person who tries to maintain her dignity in society but fails.

Debates over the applicability of tragedy to the layperson, as opposed to being the sole domain of the elite, which also happen to be mostly male and white royalty, have become extensive in the modern period and continue until today. Raymond Williams argues for the continuity of a single traditional notion of tragedy over the modern person's sense of suffering. In Modern Tragedy, he posits his wishes to resolve, "the deadlock of the contemporary contrast between 'Tragedy, proper, so-called, as known from tradition', and the forms and pressures of our own tragic experience" $(1966,16)$. In making a distinction between tragedy and the 'tragic experience', Williams underscores the material point of disagreement between the traditional and liberal views of what constitutes tragedy and who the tragic hero should be. He states that the locus of the problem is a historical approach claiming that "Tragedy comes to us, as a word, from a long tradition of European civilization, and it is easy to see this tradition as a continuity" (15). This perspective clearly attaches tragedy to specific cultural roots that by definition excludes non-Europeans from the 
experience of tragedy. Other theories on tragedy, such as that presented by Hegel, points out to the essentiality of freedom and self-determination of the tragic hero/heroine. As cited by Williams, Hegel maintains that the rich own their freedom, whereas the layperson is not fully free and that,

In genuine tragic action it is essential that the principle of individual freedom and independence, or at least that of self-determination, the will to find in the self the free cause and source of the personal act and its consequences, should already have been aroused. $(1966,33)$

This position from tragedy eliminates all underdogs of society, be it the poor, women or the marginalized, from being subjects of "genuine" tragedy because they are not free from dependence on society or family members for their subsistence. Colbert argues this assumption saying,

Parks's drama questions black people's access to freedom and independence, given the violent circumstances that often circumscribe expressions of their will. [...] Parks's drama aligns with and exceeds Arthur Miller's articulation of tragedy, which accounts for the ability of everyday people and not just "great" men and women to participate in the course of history. $(2018,200)$

In opposition to traditional doctrines on tragedy, Miller refuses to consider tragedy only as an "archaic form" that is meant to speak of the rich and famous and insists that "the common man is as apt as a subject for tragedy in its highest sense as kings were" (Miller 2015, n. pag.). Comparable to Miller, Suzan LoriParks also attempts at constructing her own historical and traditional continuity albeit of the poor and dispossessed. Unlike traditional views on tragedy, hers is not based on race or religion rather it is focused on humanity as a whole and the inherited literary traditions. She "loves these great dead authors. And Why not? For her, they are also family, literally her literary ancestors. She possesses and is possessed by them; their relationship is [...] like ownership is, or genetics" (Fraden 2007, 435). 
She therefore intertextualizes a number of elements in her plays with historical events and fictional works by other authors, in the same way that T.S. Eliot proposes that

the historical sense involves a perception, not only of the pastness of the past, but of its presence; the historical sense compels a man to write not merely with his own generation in his bones, but with a feeling that the whole of the literature of Europe from Homer and within it the whole of the literature of his country has a simultaneous existence and composes a simultaneous order. No poet, no artist of any art, has his complete meaning alone. (Eliot 2017)

While quite critical of Eliot in his cultural imperialist views of art, Edward Said acquiesces the latter literary approach declaring that "Eliot's synthesis of past, present, and future, however, is idealistic ... his central idea is valid: how we formulate or represent the past shapes our understanding and views of the present" $(1993,4)$.

It is worth noting that Parks has written two plays inspired by Nathaniel Hawthorne's novel The Scarlet Letter. These two plays are In the Blood and Fucking A. The protagonists in both plays are called Hester after Hester Pryne. In building Hester's character and tragic predicament, Parks is clearly inspired here by the protagonist and plot of Nathaniel Hawthorne's The Scarlet Letter, as, "[t]hrough the names of characters, Parks's dramas often comment on how recognizability produces compassion and, in alignment with the ancient and modern drama, allows for catharsis in response to the death of a purportedly great man (Colbert 2018, 204). Furthermore, the fact that Hester ends up killing her son herself resonates the tragic fatalism pointed out by Williams in Ibsen's play Brand,

Blood of children must be spilt

To atone for the parents' guilt. (Williams 1966, 98) 
Philip C. Kolin explains that, "Blood symbolizes Hester's sexual sins and shame," and that her blood is construed within the play as polluted (Kolin 2006, 253). In fact that concept connects her work to Greek tragedy, where pollution runs in families and becomes their impermeable sin. In his confession scene, Reverend D, who fathers her youngest illegitimate sons and is repelled by her poverty, complains that she wants to drag him down to her hunger, saying,
And now the hate I have for her
and her hunger
and the hate I have for her hunger.
God made me.
God pulled me up.
Now God, through her, wants to drag me down." (Parks 2000, 49)

Reverend D's repulsion of Hester poverty reflects a fear within him that her hunger and need, like a disease, could be contagious. He therefore disassociates himself from her and their son by refusing to give the latter his name or help her out financially.

Suzan Lori-Parks describes her writing style as based on Rep \& Rev (revision and repetition), a concept that she borrows from jazz; this "constitutive nature of recurrence functions as a method to revise and reinterpret, moving history forward rather than indulging the compulsion to rid history of its ghosts" (Colbert 2018, 201). The purpose for this is to revise historical records that have excluded African-Americans from its written documents, as "[h]er drama contains traditional tragic elements: haunting, suffering and living with death and despair, and some formal attributes" (201). Thus, creating compassion to a generally sidelined minority. From this point of view, Parks's tragic vision aligns with Miller's as per the latter articulation: "The tragic feeling is evoked in us when we are in the presence of a character who is ready to lay down his life, if need be, to secure one thing - his sense of personal dignity" (Miller 2015, n. pag.).

Personal dignity is exactly what propels Hester not to give her children up for adoption or succumb to an unfair welfare system that threatens to deform her 
femininity by forcing her to have her uterus removed in order not to litter the streets of North America with illegitimate children. In line with all tragic heroes/heroines, Parks portrays Hester as in, "a conventional tragic direction, an individual in opposition to society who will be punished for her opposition" (Fraden 2007, 440). Hester's defiance of society and her poverty are embodied in her boldly occupying public space and proudly mothering illegitimate children. To her children, she explains their fatherless situation by making up a fable-like account of their absent fathers,

And one day the five brothers heard her and came calling and she looked upon them and she said: "There are five of you, and each one is wonderful and special in his own way. But the law of my country doesn't' allow a princess to have more than one husband." And that was such bad news and they were all so in love that they all cried. Until the princess had an idea. She was after all the Princess, so she changed the law of the land and married all of them. (Parks 2000, 13)

Even in her make-belief tale, Hester imagines that she changes the law of the land to her advantage. Later on, when one of her children asks where the five husbands went, she confidently responds, "The war came and the brothers went off to fight and they all died" (13).

In spite of the enormous load of having to raise five children alone, without a partner, employment or a home, Hester still battles through her circumstances doing menial jobs and performing sexual exchanges for any financial help she can obtain. All the time she attempts to own her circumstances and resists being the racial stereotype of "the impoverished African-American women", who gives her children up for sale or adoption. She therefore makes the tough choice of bearing the result of her own decisions, as bad as they are, to take care of her children herself rather than be owned by the welfare system that threatens her with dispossession, by taking her kids away, and displacement by putting her up in a shelter, which she describes saying, "the shelter hassles me. Always prying in my business. Stealing my shit. Touching my kids" (32). From this point of 
view, Hester embodies Miller's tragic heroine for, "the underlying fear of being displaced, the disaster inherent in being torn away from our chosen image of what or who we are in this world. Among us today this fear is as strong, and perhaps stronger, than it ever was. In fact, it is the common man who knows this fear best" (Miller 2015, n. pag.). Hester's worst fear throughout the play is to be displaced and dispossessed of her space and children respectively.

At the beginning of the play, the plot depicts Hester at the highest point of contentment. Living in their home under the bridge, she cooks, cleans, irons her children's clothes and polishes their shoes as though she is in motherhood bliss. She tells her kids: "leave yr shoes for polish and yr shirts and blouses for press. You dont wanna look like you dont got nobody" (Parks 2000, 14). She is determined to make them feel loved and special; feelings she herself never experienced as people in her life continually exploit her. Hester dreams of her children fitting in a society that rejects them, and, according to her, the way to do it is by emulating the norms of that dominant society. She therefore strives to make them not feel poor, neglected or deprived to the best of her ability. At this point, in her mind, she is living the American Dream; she has a home (although on the street), children (though illegitimate), and food (only soup) to feed her children. Like all wholesome families, she calls her children to eat dinner:

\author{
Hester: Suppertime! \\ (She ladles out the soup) \\ Todays soup the day, ladies and gents, is a very special blend of \\ herbs and spices. The broth is chef Mommies worldwide famous \\ "whathaveyou" stock. Theres carrots in there. Theres meat. Theres \\ oranges. Theres pie. (Parks 2000, 11)
}

At this junction, the play captures Hester as an in control matriarch, who is trying to follow the social norms of her hegemonic cultural order, and ignoring the fact that while she is part of that society, she is construed as an unfit member residing on its periphery, indeed seen as leeching off of it. As Hester lives the illusion that her life is that of a regular lower middle-class American household, everyone around her realizes that her life is a sham for she does not actually own 
her freedom or dwelling space as she thinks that she does. Arranging her life the way she did at the beginning of the play is a reflection of Miller's notion, that, "[i]n the tragic view the need of man to wholly realize himself is the only fixed star, and whatever it is that hedges his nature and lowers it is ripe for attack and examination" (Miller 2015, n. pag.). Hester's tragic flaw is thus her excessive sense of control against all odds in her life as it is her, "inherent unwillingness to remain passive in the face of what [she] conceives to be a challenge to [her] dignity, [her] image of [her] rightful status" (Miller 2015, n. pag.). Hester refuses to perceive herself and her life as inferior or less worthy than others who have rank, education and work. This flaw induces her to subject her body to sexual exploitation by virtually everyone around her. After all, Hester's only possessions are her body and her children. While she refuses to sell or give her children up for adoption or foster homes, she opts to commodify her body instead. According to her, her body is the only way she could 'buy' her independence in a capitalist system that threatens to take her children and her reproductive organs away, not to mention putting her in a homeless shelter and off the streets. Knowing that her economic and social conditions could only lead her to either receive help from social institutions, which would be the ultimate defeat for her, because the price is her freedom, or get help from individuals, who would (meagerly) support her in return for sexual favors. She consciously chooses the second option as, in her mind, it represents a form of freedom of choice, symbolically so at the very least.

In individual monologues, which Parks calls 'confessions,' the characters in Hester's life, who take advantage of her financial need by exploiting her body, talk about their feelings toward her and explain both their attraction to and repulsion of her. They all ruminate on the extent she gives her body very generously and how that drew them back to her wanting more of her body. However, ironically, instead of them being gratified by her submissiveness, her destitution wards them off, and they all admit that while they exploited her physically, they were turned off by her abject poverty, and therefore refused to help her beyond the pittance they had given her for sexual encounters with her. If anything, the confessions reveal the deep unkindness of those who have abused Hester over the years and exposes that they despise their own selves for 
being attracted to someone whom they deem tainted and disreputable. Hester, on the other hand, exchanges sex for basic human rights of employment, medical care, child and social support. She is not afraid to work hard, but her professional skills are virtually non-existent. She realizes that the social order within which she lives would never support an illiterate, poor, single (African-American) woman and mother of five children out of wedlock. The only way she tries to gain agency is by way of aligning with the powers that be as her "fate is not determined by gods or heredity but rather by a society that cruelly withholds its support, manipulates [her] for its own benefit, and blames her for her circumstances (Schafer 2008, 194). Moreover, the limited power she has over her life as represented by her home on the streets and illegitimate children is constantly threatened to be taken away from her if she does not yield to society's harsh rules.

Hester's show of control and power is further embodied in the fact that she carries a police baton around her waist - which her son has stolen from a policeman - as a symbol of authority, autonomy and discipline, as well as for self-defense. Ironically, her tragedy is complete when in anger she kills her first born and closest to her heart, Jabber, with that same baton. Upon killing her son, Hester realizes that her ordained fate, which she had attempted to defy, had won over.

When Hester, in In the Blood, looks up in the sky and says she has seen the hand of Fate blocking out the sun "with its 5 fingers coming down on me," it feels as though she has no choice but to succumb to what fate brings to her. (Fraden 2007, 447)

This self-destructive moment captures Hester's recognition that she can no longer challenge the social order around her. At this point the plot arrives at peripeteia as she realizes the irrevocability of her tragic condition and fate. There she falls right into the social stereotypical racial category she had tried all her life to defy: that society construes her as a 'slut' and that she has to pay for that sin, which is ascribed to her by a society that exonerates itself from all assistants to the poor and disempowered. 
Her favorite son, Jabber, is the one who had shielded her from reading the word 'slut', written as graffiti on the wall next to where they live under a bridge at the beginning of the play. He erases the slur and refuses to read it out loud to her when she asks,

Jabber: Them bad boys had writing. On our house. Remember the writing they had on our house and you told me to read it and I didnt wanna I said I couldnt but that wasnt really true I could I can read but I didnt wanna.

Hester: Hush up now (Parks 2000, 64-65)

Jabber is her favorite son in the same capacity as Cordelia is to Lear in King Lear; both protagonists tragically lose their most beloved child because of their refusal to see their own hubris. At her lowest moment and when she is rejected by everyone around her, Hester still refuses to hear Jabber read the word 'slut' back to her because she is still in denial that this is how society views her. When he mindlessly reads it out loud, she screams to silence him as hearing the utterance is akin to seeing herself as or becoming the adjective. Jabber, however, does not hush up as he utters the word unintentionally; his utterance becomes the prophecy that determines her tragic fate,

(She quickly raises her club and hits him once. Brutally. He cries out and falls down dead. His cry wakes Bully, Trouble and Beauty. They look on. Hester beats Jabbers body again and again and again. Trouble and Bully back away. Beauty stands there watching. Jabber is dead and bloody. Hester looks up from her deed to see Beauty who runs off. Hester stands there alone - wet with her son's blood. Grief stricken, she cradles his body. Her hands wet with blood, she write an A on ground). (65)

With Jabber's blood, Hester writes the letter 'A', which he had tried to teach her earlier but for no avail. With his death, Hester's downfall is concluded: she loses 
her freedom, her children and her sense of self and dignity. Comparing Parks's tragic ending with Hawthornes's protagonist, Fraden asserts that

\begin{abstract}
Parks's Hesters end up in a pool of familial blood. Her Hesters gain no peace; they lose everything dear. So that finally, strikingly and strangely, Parks writes endings that are totally different from Hawthorne's in tone and substance. Hawthorne mitigates tragedy, but Parks is ruled by it, eschewing all audience watching. Tragic conventions loom overhead in both plays. Parks's Hesters are on stage, and dramatic expectations and conventions shape them differently from that of a novelistic discipline. $(2007,441)$
\end{abstract}

In prison, she laments having had her children to begin with, as well as for having tried to live a life beyond that which is sanctioned to her by society. In her final confession, she admits,

Kids? Where you gone?

Never shoulda haddem.

Me walking around big as a house

Knocked up and Showing

and always by myself...

I never shoulda haddem! (Parks 2000, 67)

Throughout the play, Hester's children are both a blessing and curse for her in a number of ways: society treats them as a disposable burden; her best friend advises her to either put them in foster homes or sell one of them to make ends meet; the Doctor wants her to remove her uterus in order to stop having more illegitimate children; the Welfare Worker warns her that she would no longer offer her minimum wage jobs if she continues to have more children; Reverend $\mathrm{D}$ who is the father of her youngest child refuses to either help her out financially or give the child his name as he perceives their child as a token of his licentious behavior; Chilli, her first lover and father of her first son, Jabber, who had 
abandoned her years ago, comes back to ask her to marry him but leaves as soon as he finds out she has had illegitimate children with other men.

In fact, Hester's romantic dreams are crushed as a result of Chilli's rejection. Upon his return, he brings her a ring and wedding dress with a veil but withdraws all when he finds out that she did not stand the test of time by loyally waiting for him. Chilli's return is the both climactic moment and turning point in the play. His return marks the only time Hester is ashamed of her children. She lies and tells Chilli that they were the neighbor's kids, but he finds out the truth and chides her saying,

I carried around this picture of you. Sad and lonely with our child on yr hip. Stuggling to make do. Stuggling against all odds. And triumphant. Triumphant against everything. Like - hell, like Jesus and Mary. And if they could do it so could my Hester. My dear Hester. Or so I thought.

(Rest)

But I don't think so.

(He takes her ring and her veil. He takes her dress. He packs up his basket.) (67)

After this Hester ends up killing her son with him in a moment of deep rage, therefore killing Jabber is akin to destroying the final vestiges of innocence and beauty left in her. The irrevocable crime of course leads to her losing all of her children to foster care and be locked forever in prison as a murder not to mention living with pain of having killed her own child.

Hester's tragedy lies mainly within the realm of her devotion for her children. Everything she had done before her fateful end was to provide for them and keep them under her guardianship. In her belief system, her children, while illegitimate, constituted her only 'possessions.' In capitalist society like the USA, ownership greatly valued and reflects the value of an individual. Thus, Hester's fanaticism about 'owning' children is a by-product of belonging to a socio-economic order that places great importance on materialism and is obsessed with consumerism. Hence, 'having' kids gives her a sense of 
domination and empowerment, which, in her mind, seems as though she was aligning with her social order. Moreover, her children also provide her with a sense of belonging, unconditional love and pride in spite of her abject poverty.

Hester makes the street her home; in her public-made-private space under the bridge, she commands control over her world, herself and children. She organizes her space according to the laws of ownership; she makes the rules and runs it like clockwork. When Amiga Gringa, prostitute and friend, proposes that she give her children up for adoption, Hester objects vehemently. It is important to note that children, from Amiga Gringa's perspective, are more-or-less commodities that could yield dividends to anyone, if exploited properly. Amiga Gringa herself has lived off of selling her children. Hester, however, refuses the idea vehemently,

Amiga: Gringa: You oughta send yr kids away. Theres plenty places that you can send them. Homes. Theres plenty of peoples, rich ones especially, that cant have kids [...]ingy Youd have some freedom. Youd have a chance at life. Like me.

Hester: My kids is mine. I get rid of em what do I got? Nothing. I got nothing now, but if they go I got less than nothing. (15)

Hester refuses to commodify her children yet in her mind they are symbols of ownership, they embody or are in lieu of property. To lose them means to be the stereotype; their presence in her life gives her value, agency and control over her life.

Her appropriation of the public space is another symbol of maintaining power. Living on the streets is a representation of both her displacement and liminality, on the one hand, but it also gives her freedom from authority, on the other hand, as she lives according to her rules and ethics. While Hester considers her occupation of public space as her protection from the abuses of social institutions, she fails to maintain her domination of that space. Hence, her tragic fall is mapped out as she ends up exactly where she had dreaded: institutionalized in prison and marginal as well as deprived of her possessions, her children, her open space in the 'center' of the public domain, the street. Furthermore, her final 
sense of self is stripped away in prison when her reproductive organs are removed, much the same way as animals are spayed.

Hester's journey from under the bridge to prison may seem stereotypical, but the humanization of the protagonist, who started out with a strong sense of dignity and wish to have "a leg up" in society to improve her economic conditions, creates a tragic figure who embodies the stereotype from which she so wished to run away.

While Hester takes responsibility for her actions, those in the audience who, by virtue of their race, gender, wealth, status, position, and/or education, remain members of the social structure that condemns Hester to her fate are forced to admit their complicity in what has occurred. While order is restored to society by Hester's downfall, the audience must question whether this order offers the hopeful beginning implicit in the conclusion of a tragedy. If there is to be hope, then the audience must change. (Schafer 2008, 193-194).

Therefore, like all poignant tragedies, the tragic hero's/heroine's downfall brings about fear and sorrow within the audience. In this case the audience is part of the problem for they are indicted in the social order that disenfranchises society's underdogs and refuses to give them a chance to experience life in the same way as the rest of the population. On the other hand, there is sorrow for the fall of the protagonist who tried to live up to the norms of a society that rejects her. Clearly, Hester fails at maintaining any sort of power as her presence in society along her terms is contested, resisted and downright disdained. In prison other prisoners confirm her stereotypical status in a ritual that confirms her limitations and inscribes her tragic fall:

(They spin)

SHE DONT GOT NO SKILLS

CEPT ONE

CANT READ CANT WRITE

SHE MARRIED? . . 
UST PLAIN STUPID IF YOU ASK ME AINT NO SMART WOMAN GOT ALL THEM BASTARDS

AND NOT A PENNY TO HER NAME (Parks 2000, 68-69)

Hester's battle with the social injustice ends with her becoming the essence of tragedy. She is cast away as do all criminal elements in society and taken from the center of life on the streets to the margins of society in prison, and there she will be literally neutered as they remove her uterus, and will be expected to 'perform' her socio-economic marginal status as inferior and inept.

\section{Works Cited}

Aristotle. 1961. Aristotle's Poetics. Translated by S. H. Butcher, New York: Hill and Wang.

Bachelard, Gaston. 1969. The Poetics of Space: The Classic Book at How We Experience Intimate Places, Massachusetts: Beacon Press.

Colbert, Soyica Diggs. 2018. "Suzan-Lori Parks," Visions of Tragedy in Modern American Drama, London \& New York: Bloomsbury, Methuen Drama, 199213.

Eliot, T.S. 2017. "Tradition and the Individual Talent (1919)." $<$ https://people.unica.it/fiorenzoiuliano/files/2017/05/tradition-and-theindividual-talent.pdf $>$. Accessed on February 11, 2020 at 7:11 pm.

Fraden, Rena. 2007. "Suzan-Lori Parks' Hester Plays: 'In the Blood and Fucking A."' The Massachusetts Review, vol. 48, no. 3.

$<$ www.jstor.org/stable/25091230. Accessed 6 Feb. 2020>.

Kolin, Philip C. 2006. "Park's In the Blood." The Explicator, vol. 64, no. 4. $<$ https://resolver.scholarsportal.info/resolve/00144940/v64i0004/253_pitb.x $\mathrm{ml}>$.

Miller, Arthur. 2015. "Tragedy and the Common Man." mr.shannon.com/wpcontent/2015/05/tragedymillerandartistotle.pdf. Accessed February 10.

Parks, Suzan-Lori. 2000. In the Blood, New York: Dramatists Play Service inc.

Said, Edward W. 1993. Culture and Imperialism, New York: Alfred A. Knopf.

Schafer, Carol. "Staging a New Literary History: Suzan-Lori Parks's Venus, In the Blood, and Fucking A," Comparative Drama. Vol. 42, no. 2, 2008, 181203. www.jstor.org/stable/23038019.

Williams, Raymond. 1966. Modern Tragedy, Stanford, California: Stanford University Press. 